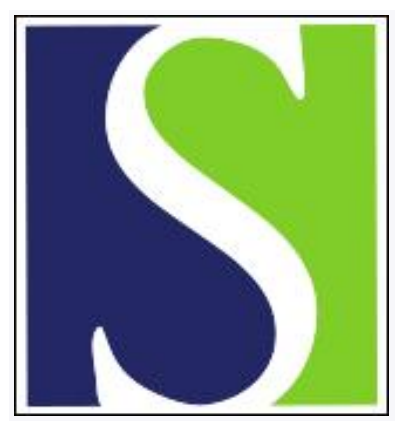

Scand J Work Environ Health 1976;2(2):87-95

https://doi.org/10.5271/sjweh.2820

Issue date: Jun 1976

Transmission of vibration in the hand-arm system with special reference to changes in compression force and acceleration.

by Pyykkö I, Färkkilä M, Toivanen J, Korhonen O, Hyvärinen J

The following article refers to this text: 2017;43(3):191-195

Key terms: acceleration; arm; chain saw modeling; compression force; hand; hand-arm system; tissue resonance; vibration; vibration attenuation; vibration syndrome; vibration transmission

This article in PubMed: www.ncbi.nlm.nih.gov/pubmed/959789

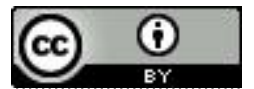




\title{
Transmission of vibration in the hand-arm system with special reference to changes in compression force and acceleration
}

\author{
by ILMARI PYYKKÖ, M.D., ${ }^{1}$ MARKUS FÄRKKILÄ, B.Sc., ${ }^{2}$ \\ JARMO TOIVANEN Lic. Tech., ${ }^{3}$ OLLI KORHONEN, M.D.,4 \\ and JUHANI HYVÄRINEN, M.D.2
}

\begin{abstract}
PYYKKÖ, I., FÄRKKILÄ, M., TOIVANEN, J., KORHONEN, O. and HYVÄRINEN, J. Transmission of vibration in the hand-arm system with special reference to changes in compression force and acceleration. Scand. $j$. work environ. \& health 2 (1976) 87-95. The transmission of longitudinal vibration in the hand-arm system of five subjects was investigated. Altogether 405 individual tests were made. Vibration was measured with an accelerometer (weight $0.4 \mathrm{~g}$ ) fixed in turn to the wrist, the elbow, and the upper arm by means of a supporting device (weight $34 \mathrm{~g}$ ). A handle with strain gauges attached was used to study the effect of compression force $(10,20$ and $40 \mathrm{~N}$ ) and constant acceleration $(1,3$ and $10 \mathrm{~g})$ on the transmission of vibration at frequencies from 20 to $630 \mathrm{~Hz}$. In the curves recorded, sharp dips appeared which were evidently caused by resonances from the soft tissues of the hand. However in the hand-arm system no common resonance frequency was observed that would harmfully affect the health of workers. Vibration in the hand-arm system was attenuated at an average of $3 \mathrm{~dB}$ per octave at the frequencies between 20 and $100 \mathrm{~Hz}$. Between 100 and $630 \mathrm{~Hz}$ the attenuation was about $6 \mathrm{~dB}$ per octave in the wrist and $10 \mathrm{~dB}$ per octave in the elbow and upper arm. At the frequency of $630 \mathrm{~Hz}$ the attenuation was hence about $35 \mathrm{~dB}$ in the wrist and about $45 \mathrm{~dB}$ in the elbow. The attenuation of vibration in the elbow joint was 2 to $4 \mathrm{~dB}$ at all frequencies. The hand-arm system appears to be linear at the acceleration range considered; the increase in handle vibration by, e.g., $10 \mathrm{~dB}$ also increased vibration in the hand by $10 \mathrm{~dB}$. When the grip strength was increased fourfold, i.e., $12 \mathrm{~dB}$, vibration increased only 3 to $5 \mathrm{~dB}$ in the hand-arm system. Thus changing the weight of a vibrating tool does not reduce vibration enough. Therefore attempts to reduce vibration should concentrate on the mechanical parts of the engines.
\end{abstract}

Key words: vibration syndrome, hand-arm system, vibration transmission, tissue resonance, compression force, acceleration, chain saw modeling, vibration attenuation.

1 Ear, Nose and Throat Clinic of the University Central Hospital, Helsinki, Finland.

2 Institute of Physiology, University of Helsinki, Helsinki, Finland.

3 Helsinki University of Technology, Espoo, Finland.

4 Department of Physiology, Institute of Occupational Health, Helsinki, Finland.

Reprint requests to: Dr. Ilmari Pyykkö, Ear, Nose and Throat Clinic, University Central Hospital, Haartmaninkatu 4, FIN-00290 Helsinki 29, Finland.
The vibration syndrome is prevalent in men operating vibrating tools $(1,4,11,20)$. It consists of symptoms which indicate the involvement of the vascular regulatory system, peripheral and central nerves, bone and articular tissue, and the muscles of the hands $(17,19,35,36)$. The most prominent symptom of this disease is the periodical blanching of fingers in a cold environment, the so-called traumatic vasospastic disease (TVD) or vibra- 
tion-induced white finger $(9,33)$. In contrast to, e.g., collagen disease these circulatory disturbances almost never cause atrophy or necrosis of the fingers. Although several etiological mechanisms have been proposed for vibration syndrome, it is debatable whether the different symptoms in various organs have a vascular origin or whether they are caused by the direct influence of vibration on the organs involved $(12,21,23,31)$.

The affinity of the syndrome to men using vibrating tools depends on factors such as operation time, weight of the tool, manner of handling the tool, dominant frequency of vibration, etc. It has even been suggested that body constitution plays an important role in the etiology of the vibration syndrome $(11,34)$. In Finland it has been estimated that about $40 \%$ of the 40,000 professional lumberjacks are disabled by vibration syndrome $(10,24)$.

Mechanically the hand-arm system consists of solid bones linked elastically by joints and muscles. According to von Bekesy (3) and Keidel (16) the vibration properties of the hand-arm system resemble closely that of solid bars joined together with elastic material so that the system makes both translational and rotational movement when exposed to vibration. Dieckman (5) and Reynolds and Soedel (29) have shown that the muscles influence this system by changing the mechanical impedance. Inspite of the fact that the importance of grip force on the handle of the vibrating tool is well documented and the fact that the physiological and mechanical process in the muscles of the hand during vibration is well known, the relation of grip force to the transmission of vibration from a tool to the hand is not properly understood.

Information on the resonance frequency in the hand-anm system is contradictory. Iwata et al. (14) found that the hand-arm system is resonant at frequencies below $5 \mathrm{~Hz}$ and between 30 and $40 \mathrm{~Hz}$. Dieckman proposed that resonance occurs between 40 and $70 \mathrm{~Hz}$, whereas Teisinger (34) pointed out that no remarkable resonance frequencies exist in the hand-arm system.

Attenuation of vibration in different parts of the hand-arm system has not been sufficiently clarified. Most studies have focused mainly on moderately low frequencies, up to $100 \mathrm{~Hz}$, and little attention has been paid to the high frequency vibration considered especially harmful in causing TVD $(1,8,25)$.

In this study we used a dynamic shaker to measure the transmission of vibration of up to a frequency of $630 \mathrm{~Hz}$ in the hand-arm system. We also measured the effect of different compression forces on the transmisson of vibration.

\section{SUBJECTS AND METHODS}

Five subjects were tested, one of which was left-handed. Two of the subjects were professional lumberjacks (aged 39 and 48 years), and three (aged 22, 29, and 29 years) were members of our investigating team.

A block diagram of the equipment used is shown in fig. 1. To evoke vibration in the hand, we used a dynamic shaker (Ling 403). The shaker was placed longitudinally on the antebrachium. It was driven by sinusoidal sweeps beginning at frequencies of either 20,50 , or $100 \mathrm{~Hz}$ and proceeding up to $630 \mathrm{~Hz}$. The lowest frequency depended on the acceleration used. The duration of the sweep from 20 to $630 \mathrm{~Hz}$ was about $5 \mathrm{~min}$. Because momental changes in muscle tone like those caused by tonic vibration reflex could have interfered with the propagation of vibration, we preferred a slow sweep to a fast one.

The acceleration of the shaker was recorded by an accelerometer (Brüel and Kjaer 4330) fixed to the handle. The output voltage of the accelerometer was amplified and used for the control of the acceleration, which was held constant to an accuracy of about $0.5 \mathrm{~dB}$.

We measured the vibration transmitted to the hand-arm system with an accelerometer (Brüel and Kjaer 8304) weighing $0.4 \mathrm{~g}$. A plexiglass form was used as the support, and it kept the accelerometer longitudinal to the vibration. It was placed in turn on the styloid process in the wrist, on the olecranon in the elbow, and on the medial epicondylus in the upper arm. 


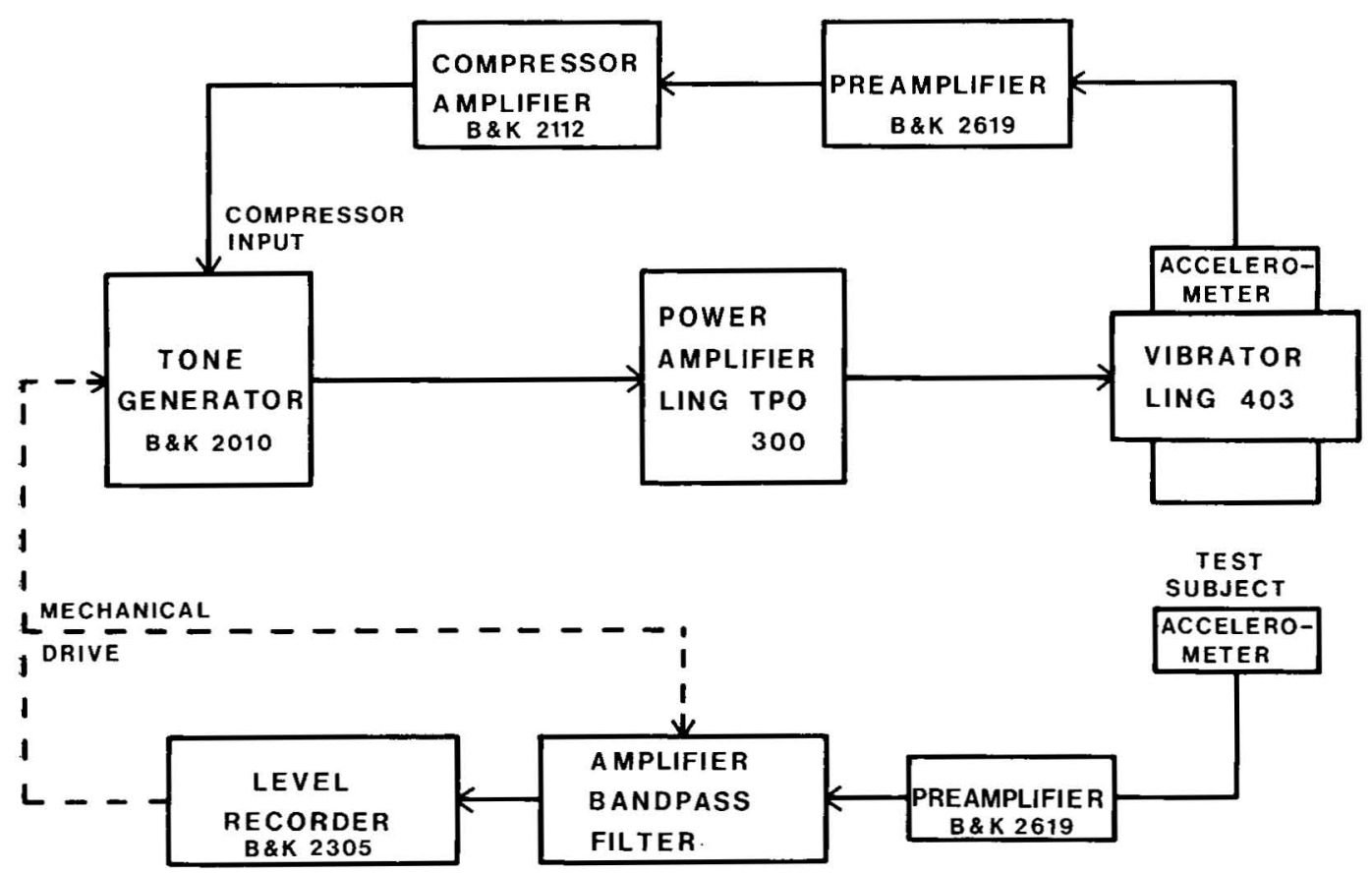

Fig. 1. Block diagram of the test apparatus. (B \& $K=$ Brüel and Kjaer)

A metal ring with screws held the measuring system in position. We used a rigid fixation in order to eliminate the responses of the cutaneous, subcutaneous, and connective tissue around the bones because such tissue response could have interfered with the attenuation of vibration. The total weight of the measuring system was $34 \mathrm{~g}$. Since the sensitivity of the accelerometer was low and electrical noise could have greatly influenced the recordings, we used a $3.16 \mathrm{~Hz}$ band-pass filter (Brüel and Kjaer 2010), which followed the frequency of the generator. The vibration level was recorded as a function of frequency on paper calibrated for frequency and acceleration.

For measurement of grip (compression) force, the handle of the shaker consisted of two metal bars with strain gauges (diameter $25 \mathrm{~mm}$ ). The output voltage of the strain gauges was recorded with an ink writer (Watanabe H611). The subject kept the grip force constant by following the signal of the strain gauges on the ink writer.

The subject sat during the test with his upper arm $30^{\circ}$ below the horizontal level and the elbow joint at an angle of $120^{\circ}$. The shaker was placed longitudinally on the antebrachium.

The tests were made at an acceleration of either 1,3 (more exactly 3.16 ), or $10 \mathrm{~g}$ (rms values). The lowest comparable frequencies measured were 20,50 , and 100 $\mathrm{Hz}$, respectively. At lower frequencies the vibration could have been severely distorted because the vibration amplitude would have been too high for the shaker. At each acceleration we measured the influence of grip force $(10,20$ and $40 \mathrm{~N})$ on the transmission of vibration. All measurements were made three times at intervals of some days between the measurements. Hence we made a total of 405 recordings.

\section{RESULTS}

Shape of a single recording

In most recordings we found the deep and narrow dips shown in fig. 2 . In the 


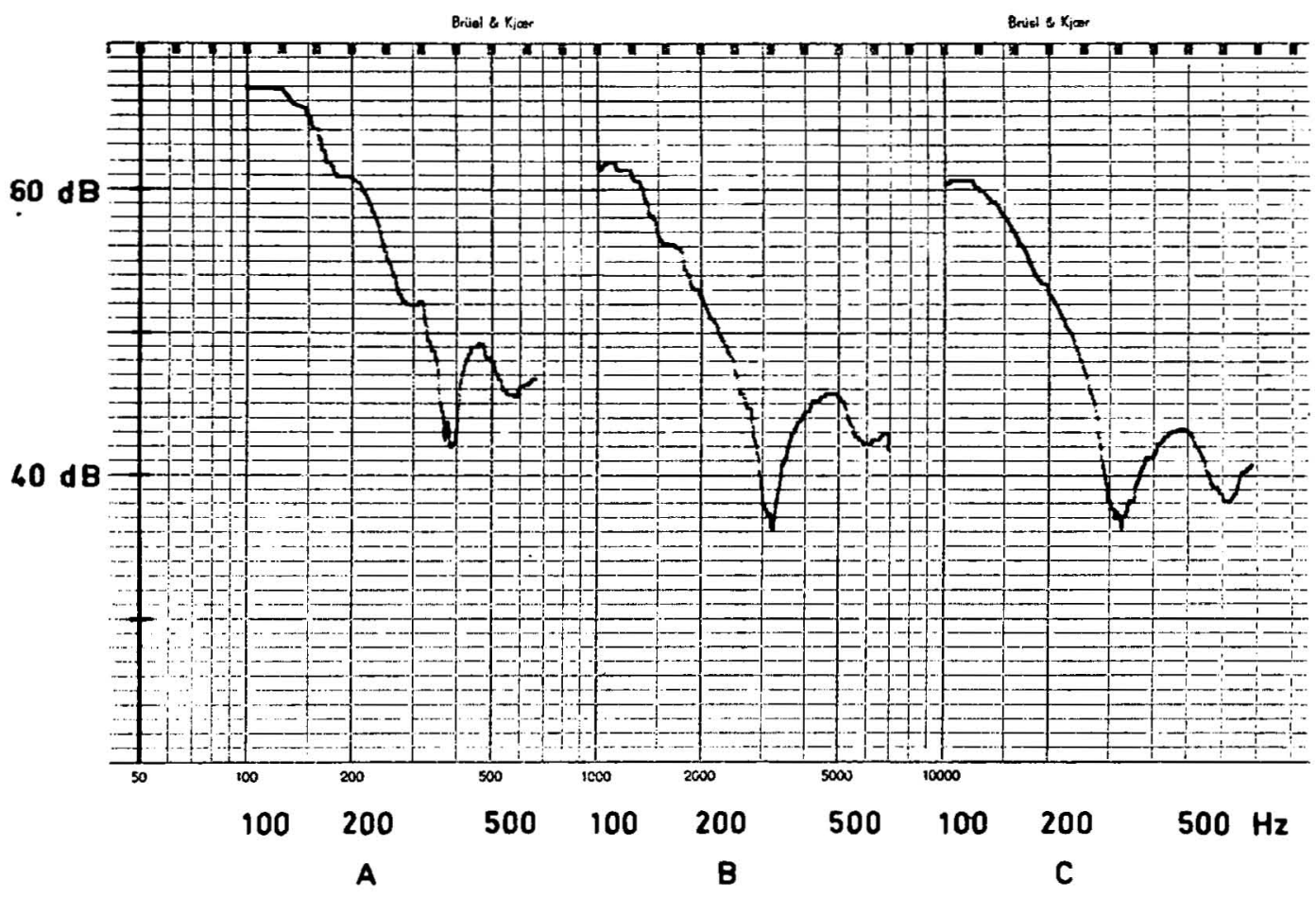

Fig. 2. Typical curves recorded from the elbow on paper calibrated for frequency and acceleration. The excitation level equaled $10 \mathrm{~g}$; and the compression force, $40 \mathrm{~N}(\mathrm{~A}), 20 \mathrm{~N}$ (B), and $10 \mathrm{~N}(\mathrm{C})$.

location of the dips the intraindividual variation was slight, but the interindividual variation was great. An increase in compression force or the intensity of vibration moved the dips towards higher frequencies. To obtain numerical data, we analyzed the recordings at preferred frequencies (13) at $1 / 3$ octave intervals. After this operation the individual shape of the curves disappeared.

Attenuation of vibration in the hand-arm system

Relationship between the intensity and frequency of vibration. The mean of all the recordings was reconstructed to correspond with an acceleration of $3 \mathrm{~g}$ (fig. 3). At a frequency of $20 \mathrm{~Hz}$ the attenuation of the vibration in the wrist was $10 \mathrm{~dB}$; in the elbow, about $12 \mathrm{~dB}$; and in the upper arm, about $14 \mathrm{~dB}$. When the frequency of vibration was increased, the attenuation also increased. At a frequency of $630 \mathrm{~Hz}$ in the wrist the attenuation was. $35 \mathrm{~dB}$; and in the elbow and upper arm, $45 \mathrm{~dB}$.

The transmission of vibration was equal in the upper arm and elbow but differed from that in the wrist at higher frequencies. The attenuation of the vibration in the wrist grew approximately $3 \mathrm{~dB}$ per octave at the frequencies between 20 and $100 \mathrm{~Hz}$, whereas the slope at higher frequencies was about $6 \mathrm{~dB}$ per octave. In the elbow and upper arm the attenuation of vibration was of the same magnitude. as in the wrist at the frequencies of 20 to $100 \mathrm{~Hz}$, but at frequencies above $100 \mathrm{~Hz}$. the slope was about $10 \mathrm{~dB}$ per octave. In the upper arm the vibration was attenuated by 2 to $4 \mathrm{~dB}$ more than in the elbow at all frequencies. This attenuation took place mainly in the elbow.

The vibration level in the elbow exceeded that in the wrist at the frequencies of 80 to $160 \mathrm{~Hz}$, but at other frequencies. 


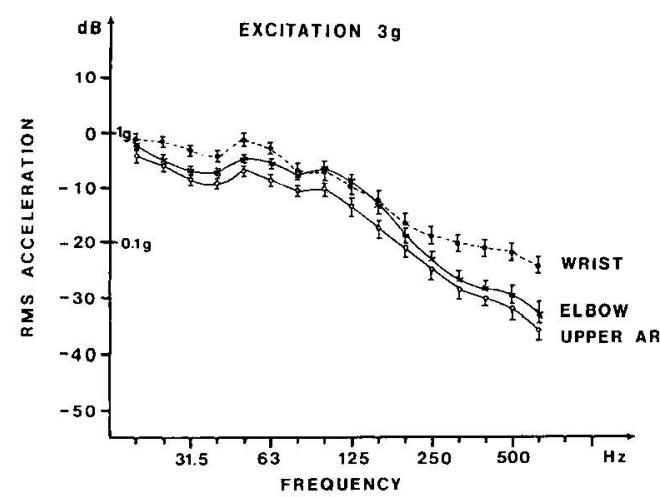

Fig. 3. Attenuation of vibration in the handarm system at frequencies from 20 to $630 \mathrm{~Hz}$. The excitation level was reconstructed to correspond with an acceleration of $3 \mathrm{~g}$.

the vibration level was lower, the difference being $7 \mathrm{~dB}$ at $630 \mathrm{~Hz}$. As the recordings were made at both ends of the same bone (radius), the result gives the transmission properties of bone tissue for longitudinal vibration.

Relationship between acceleration and the transmission of vibration. Results recorded from the elbow at accelerations of 1,3 , and $10 \mathrm{~g}$ are shown in fig. 4 . When we increased the acceleration by $10 \mathrm{~dB}$, e.g., from 1 to $3 \mathrm{~g}$ or from 3 to $10 \mathrm{~g}$, the vibration in the hand-arm system increased $10 \mathrm{~dB}$. This increase was of the same magnitude at different frequencies. Hence the hand-arm system was linear in the acceleration range considered.

Relationship between compression force and the transmission of vibration. Fig. 5 shows the effect that the increase in compression force from 10 to $40 \mathrm{~N}$ had on the transmission of vibration in the elbow at an acceleration of $3 \mathrm{~g}$. The difference between the two curves is only 3 to $5 \mathrm{~dB}$. Hence an increase in compression force of 10 to $40 \mathrm{~N}$, which is equivalent to $12 \mathrm{~dB}$, causes an increase in vibration of only about $4 \mathrm{~dB}$ in the hand. Recordings from the wrist and the upper arm yielded similar results. It can be concluded that the vibration level in the hand-arm system is proportional to the cubic root of compression force.

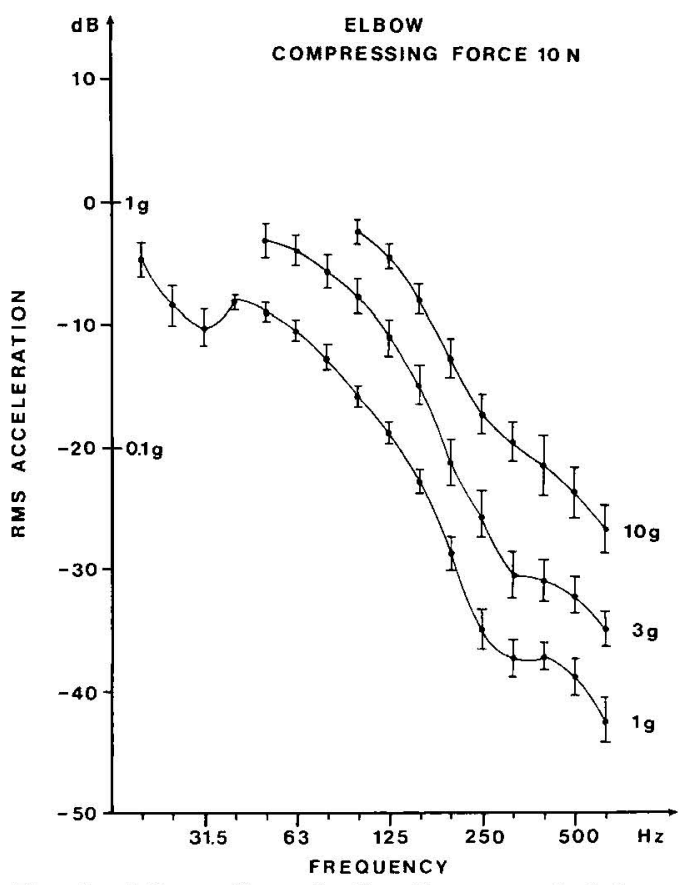

Fig. 4. Attenuation of vibration recorded from the elbow at the excitation levels of 1,3 , and $10 \mathrm{~g}$. The compression force was $10 \mathrm{~N}$. The difference in the curves was about $10 \mathrm{~dB}$, a figure equivalent to the acceleration.

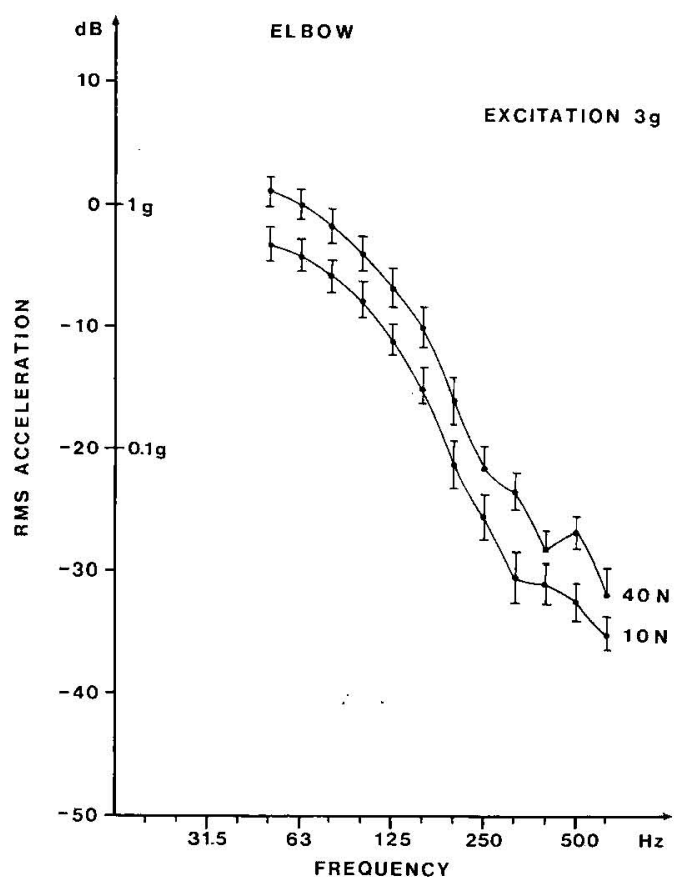

Fig. 5. Attenuation of vibration recorded from the elbow at the excitation level of $3 \mathrm{~g}$. The compression forces in the curves were 10 and $40 \mathrm{~N}$. The difference between the curves was about $4 \mathrm{~dB}$, whereas that between the compression forces was $12 \mathrm{~dB}$. 


\section{DISCUSSION}

Attenuation of vibration in the hand-arm system

A considerable attenuation of vibration occurred at high frequencies and mainly in the palm and the wrist. The hand-arm system operates thus as a low-pass filter. The properties of this filter change at a frequency of about $100 \mathrm{~Hz}$. The attenuation of the filter increases about $3 \mathrm{~dB}$ per octave at the frequencies between 20 and $100 \mathrm{~Hz}$, and between 100 and $630 \mathrm{~Hz}$ the slope is from 6 to $10 \mathrm{~dB}$. Changes in the acceleration or compression force had no significant effect on the shape of the curve.

Iwata et al. (14) studied the properties of the hand-arm system by using varying psychophysical compression forces at an acceleration level of $2 \mathrm{~g}$ in the frequency range from 6.3 to $100 \mathrm{~Hz}$. They reported results similar to ours in the frequency range of 20 to $100 \mathrm{~Hz}$. They showed moreover that at frequencies below $20 \mathrm{~Hz}$ the hand-arm system has a resonant point at which the vibration measured from the wrist exceeds that of the acceleration level two- to threefold. Hence at very low frequencies (from 6.3 to $20 \mathrm{~Hz}$ ) the handarm system operates like an amplifier. However, this kind of amplifying property is probably without any harmful health effects, since it is assumed that vibration at such low frequencies does not cause TVD (20).

Frequency response of the hand-arm system

Mechanically the hand-arm system consists of solid material, e.g., bones, which are elastically connected in the joints. When the system is exposed to vibration, both translational and rotational movements take place $(3,16)$. The bones of the upper and lower arm therefore vibrate rotationally around transient poles. The attenuation of vibration takes place mainly in the joints.

In the curves we noticed deep and narrow dips which probably resulted from resonances in the soft tissues of the upper arm. The location of the resonance frequencies mainly depended on the mass and compliance of the hand-arm system, the latter depending, e.g., on muscle tone. Hence the enhancement of muscle tone increased the rigidity of the system and shifted the velocity maximum in the soft tissues towards higher frequencies. The resonance dips seen in the curves were however so narrow that they probably have no general significance in the vibration response of the hand, e.g., in work situations.

The resonance frequencies might be important in the genesis of vibration disorders through a mechanism similar to that which has produced harmful whole body vibration. No remarkable resonance frequencies common to all measurements could be detected when the hand-arm system was studied in a normal work position. This result has been confirmed by Teisinger (34). However Dieckman (5) has pointed out that the hand-arm system has a resonance frequency of about 30 to $40 \mathrm{~Hz}$. Dieckman however defined resonance frequency as the frequency at which the mechanical impedance of the whole hand-arm system, as seen from the handle of a tool, is purely resistive. On the other hand, in our study, resonance was considered to occur when a prominent dip was observed in the frequency response of the hand-arm system. Hence these different measuring methods and definitions for resonance probably caused the apparent discrepancies.

Some increase in the vibration response of the hand-arm system could however be noticed at the frequency of $50 \mathrm{~Hz}$. At this frequency resonance evidently takes place in cutaneous, subcutaneous, and muscle tissues. Probably this resonance caused the peaks in the mechanical impedance noticed by some investigators (5, 29).

The resonance frequency of the bones to longitudinal vibration seems to be between 80 and $160 \mathrm{~Hz}$, surprisingly low figures considering the extreme rigidity of the tissue. Suggs (32) revealed similar resonance frequencies by using accelerometers fixed with screws to the bones of cadavers. A somewhat higher frequency $(250 \mathrm{~Hz})$ was however reported by Scherrick (30).

The attenuation of vibration in the joints was 3 to $5 \mathrm{~dB}$ at all frequencies. No 
significant resonance frequencies were observed. However, if one considers the joints in the hand-arm system as springs in a massive spring system, resonance frequencies should exist $(5,29)$. The elbow joint is supported by connective tissue and muscles in such rigidity that the resonance frequencies probably occur at high frequencies outside the range used in our tests.

Effect of compression force on transmission of vibration

Teisinger (34) proposed that the methods used to operate vibrating tools influence the occurrence of TVD. New unskilled workers use a tight grip on the tool and therefore allow high levels of vibration to be transmitted to their hands, while older, more skilled workers support the vibrating device lightly. The weight of tools has even been limited to $10 \mathrm{~kg}$ in some vibration standards [the Soviet standards from 1971 and the Checkoslovakian hygienic norms for vibration from 1969 (18)], because a heavy tool demands a strong grip.

An increase in muscle tone also increased the transmission of vibration in the hand-arm system. However the gain was not as high as expected. By increasing muscle tone fourfold, e.g., from 10 to $40 \mathrm{~N}(12 \mathrm{~dB})$, the vibration in the hand-arm system increased only about 4 $\mathrm{dB}$. Hence the vibration transmitted to the hand-arm system seemed to be proportional to the cubic root of the compression force. This connection did not depend upon the frequency of the vibration or the measurement point.

One could speculate that the use of lighter tools than those presently being used would reduce the vibration reaching the operator and vibration disorders would become less severe. However, to reduce the vibration level of a $10-\mathrm{kg}$ tool by $10 \mathrm{~dB}$, one must reduce the weight of the tool to $300 \mathrm{~g}$. In addition the vibration emitted from a tool is proportional to the power of the tool but inversely proportional to the weight (22). Hence, if one decreases the weight of the tool but leaves the power the same, the intensity of the vibration of the tool increases. Reducing the weight of chain saws without reducing the power was one of the causes of a high morbidity of TVD among Finnish lumberjacks in the 1960 s $(2,26)$.

The results suggest that an increase in the weight of the tool would reduce the vibration level. However this solution seems unrealistic since, in addition to vibration disorders, workers often suffer from symptoms caused by the handling of heavy tools, e.g., strained muscles and joints. A remarkably good example of the lessening of strain symptoms has been given by Pyykkö (26), who studied lumberjacks using chain saws that were $2 \mathrm{~kg}$ lighter than the ordinary model. From the ergonomic point of view a reduction in the weight of vibrating tools is justified if the effect on vibration is kept in mind.

\section{Dynamic response of the muscles}

One physiological reaction that takes place when the hand-arm system is exposed to vibration is a contraction of the muscles, the tonic vibration reflex (TVR) (6). Even the smooth vibration of the modern chain saw is capable of causing this reflex (27). It can be speculated that during work, when a reflex involuntarily increasing muscle tone is operating, muscle fatigue may develop. An uncontrolled increase in muscle tone may even diminish dexterity, interfere with natural protective reflexes, and therefore increase the risk of having an accident.

Although some momentary changes in compression force occurred at the start of the experiment, especially at the acceleration of $10 \mathrm{~g}$, the process of adaptation rapidly took place, and test subjects did not have any difficulties in maintaining the predetermined force of compression. The lack of a disturbing TVR probably resulted from the activation of both flexor and extensor muscles in the hand and arm. Hence it seems unlikely that TVR could play any important role in work conditions as long as the acceleration level is not exceptionally high.

\section{Protective measures}

The vibration level of the modern chain saw is so high $(22,28)$ that, in spite of the 
hand-arm system, the whole organism is subjected to it and a high level of vibration can be detected even in the ankles (15). Different mechanisms for the attenuation of vibration have been developed, e.g., protective (absorbing) gloves, rubber and spring insulators, balanced engines, etc. $(5,7,22)$. Protective gloves do not reduce the level of vibration, but they do interfere with work safety $(22,34)$. Experience with the insulation of the front handle of the chain saw has shown promise $(26,33)$, but the same method does not seem to be successful for the rear handle because the rear and front handle become harmfully resonant (22).

The solution to vibration disorders in workers seems to be a radical reduction of tool vibration itself. An engine with two pistons could be the solution for chain saws (22), but the problem of the heavy weight of these tools remains unresolved. The balancing mechanism in engines developed by a Finnish foundation (SITRA) is promising (7), but these engines are more complicated and thus require more practical experience.

Physiological experiments and available data indicate that vibration at low frequencies is not so harmful as that at higher frequencies $(1,8,25)$. A decrease in the dominant frequencies of vibrating tools could probably reduce the prevalence of vibration disorders. The linear response of the hand-arm system to vibration, together with the nonlinear dependence of vibration transmission on compression force, indicates that it is important to produce tools in which the genesis of vibration has been decreased, e.g., by balancing the engine. Changing the weight of the tool is not likely to reduce the vibration level remarkably.

\section{REFERENCES}

1. AGATE, J. N. and DRUETT, H. A. A study of portable vibrating tools in relation to the clinical effects which they produce. Br. j. ind. med. 4 (1947) 141-163.

2. AHO, K. Method of measuring the vibration of chain saws and evaluating the results (Vakola study report no. 8). Valtion Maatalous Tutkimuslaitos, Rukkila 1971, pp. $1-19$.

3. BEKEsY, G. VON Ubber die Empfindlichkeit des stehenden und sitzenden
Menschen gegen sinusförmige Erschütterungen. Akust. Z. 4 (1939) 360-363. Cited by Keidel (15).

4. DART, E. E. Effects of high speed vibrating tools on operators engaged in the airplane industry. Occup. med. 1 (1946) 515-550.

5. DIECKMAN, D. Ein mechanisches Model für das schwingungserregte Hand-ArmSystem des Menschen. Int. Z. Angew. Physiol. Einschl. Arbeitsphysiol. 17 (1958) 125132.

6. EKLUND, G. and HAGBARTH, K.-E. Normal variability of tonic vibration reflexes in man. Exp. neurol. 16 (1966) 80-92.

7. FÅGELHOLM, C.-M. and MÄKINEN, V. O. Sitran moottorisahaprojekti: Moottorisahatoimikunnan loppuraportti [SITRA's motor saw project: Final report of the committee studying motor saws] (Tutkimussopimus no. 4028). Suomen Itsenäisyyden Juhlavuoden Rahasto, Helsinki 1972. 27 p.

8. GERBIS, H., GROSS, A., MEYER-BRODNITZ, K. R. and ROBINSON, J. Die Verhütung von Gesundheitsschädigungen durch Anklopmaschinen. Berlin 1931. Cited by Agate and Druett (1).

9. GURDJIAN, E. S. and WALKER, L. W. Traumatic vasospastic disease of the hand (white fingers). J. am. med. assoc. 129 (1945) 668-672.

10. HEIKINHEIMO, L., HEIKINHEIMO, M. LEHTINEN, M. and REUNALA, A. Suomalainen metsätyömies [The Finnish lumberjack]. Werner Söderström Osakeyhtiö, Porvoo 1972, pp. 9-20.

11. HELLSTRÖM, B. and LANGE ANDERSEN, K. Vibration injuries in Norwegian forest workers. $\mathrm{Br}$. j. ind. med. 29 (1972) 255-263.

12. HYVÄRINEN, J., PYYKKO, I. and SUNDBERG, S. Vibration frequencies and amplitudes in the aetiology of traumatic vasospastic disease. Lancet 1 (1973) 791-794.

13. INTERNATIONAL ORGANIZATION FOR STANDARDIZATION. Acoustics-Preferred frequencies for measurements (ISO 266). Geneva 1975.

14. IWATA, H., DUPUIS, H. and HARTUNG, E. Übertragung von horizontalen Sinusschwingungen auf die oberen Extremitäten bei Halbpronationsstellung und Reaktion des M. biceps. Int. Arch. Arbeitsmed. 30 (1972) 313-328.

15. KÁKOSY, T. and SZEPESI, L. Effects of vibration exposure on the localization of Raynaud's phenomenon in chain saw operators. Work-environ.-health 10 (1973) 134 -139 .

16. KEIDEL, W.-D. Vibrationsreception. Der Erschütterungssinn des Menschen. Universitätsbund Erlanger e.V., Erlangen 1956. $154 \mathrm{p}$.

17. KLIMKOVA-DEUTSCHOVA, E. Neurologische Aspekte der Vibrationskrankheit. Int. Arch. Gewerbepathol. Gewerbehyg. 22 (1966) 297-305.

18. KRYŠ, B. The Czeckoslovakian hygiene regulation on protection against vibration. Work-environ.-health 7 (1970) 51-56. 
19. KUMLIN, T., WIIKERI, M. and SUMARI, $P$. Radiological changes in carpal and metacarpal bones and phalanges caused by chain saw vibration. $B r$. j. ind. med. 30 (1973) $71-73$.

20. MAGOS, L. and OKOS, G. Raynaud's phenomenon: The situation in the Hungarian iron, steel and engineering industry. Arch. environ. health 7 (1963) 341-345.

21. MARSCHALL, J., POOLE, E. B. and REYNARD, W. A. Raynaud's phenomenon due to vibrating tools. Lancet 1 (1954) 11511156.

22. NÄSLUND, U. Design problems in the reduction of vibration in chain saws. In: W. TAYLOR (ed.), The vibration syndrome. Academic Press, London 1974, pp. 61-70.

23. NALĈA, I. F. [Vascular disorders and their pathogenesis in connection with vibration disease.] Sov. med. 34 (1971) 11-14. (English abstract)

24. PYYKKO, I. The prevalence and symptoms of traumatic vasospastic disease among lumberjacks in Finland. Work-environ.health 11 (1974) 118-131.

25. PYYKKO, I. A physiological study of the vasoconstrictor reflex in traumatic vasospastic disease. Work-environ-health 11 (1974) $170-186$.

26. PYYKKO, I. Katsaus tärinän terveydellisiin haittoihin [Review of the harmful effects of vibration on health]. XXII työterveyspäivät. Institute of Occupational Health, Helsinki 1975, pp. 35-48.

27. PYYKKÖ, I. and HYVARINEN, J. The physiological basis of the traumatic vaso- spastic disease: A sympathetic vasoconstrictor reflex triggered by high frequency vibration? Work-environ.-health 10 (1973) $36-47$.

28. REYNOLDS, D. D. and SOEDEL, W. Vibration testing of chain saws. In: W. TAYLOR (ed.), The vibration syndrome. Academic Press, London 1974, pp. 91-108.

29. REYNOLDS, D. D. and SOEDEL, W. Dynamic response of the hand-arm system to sinusoidal input. In: W. TAYLOR (ed.), The vibration syndrome. Academic Press, London 1974, pp. 149-168.

30. SCHERRICK, C. E. JR. Variables affecting sensitivity of the human skin to mechanical vibration. J. exp. psychol. 5 (1953) 273282.

31. STEWARD, A. M. and GODA, D. F. Vibration syndrome. $B r . j$. ind. med. 27 (1970) $19-27$.

32. SUGGS, C. W. Modelling of the dynamic characteristic of hand-arm system. In: W. TAYLOR (ed.), The vibration syndrome. Academic Press, London 1974, pp. 169-186.

33. TAYLOR, W., PELMEAR, P. L. and PEARSON, J. Raynaud's phenomenon in forestry chain saw operators. In: W. TAYLOR (ed.), The vibration syndrome. Academic Press, London 1974, pp. 121-139.

34. TEISINGER, J. Vascular disease disorders resulting from vibrating tools. $J$. occup. med. 14 (1972) 129-133.

35. TELEKY, L. Pneumatic tools. Occup. health 1 (1938) 1-12.

36. VAINIO, K. Om vibrationssyndrom, särskilt hos maskinborrare. Nord. hyg. tidskr. 31 (1950) 249-265. 